\title{
Genetic Polymorphism of Epidermal Growth Factor Gene as a Predictor of Hepatocellular Carcinoma in Hepatitis C Cirrhotic Patients
}

\author{
Ibrahim Baghdadi ${ }^{1}$, Khaled Abu Ella ${ }^{2}$, Ahmed El Shaarawy ${ }^{3}$, Elsayed Elshayb ${ }^{1}$, \\ Hala S El-Rebey ${ }^{4}$, Mohamed M El Hoseeny ${ }^{5}$, Mary Naguib ${ }^{3}$, Ali Nada ${ }^{6 *}$
}

\begin{abstract}
Background: In Egypt, the incidence of hepatocellular carcinoma (HCC) is approximately $4.7 \%$ of chronic liver disease patients due to (HCV) infection. Epidermal growth factor (EGF) plays an important role in hepatocyte regeneration. A functional polymorphism in $E G F \quad 61 A>G$ was identified; itwas associated with higher risk of HCC. Objectives: to investigate the correlation between the epidermal growth factor $(E G F)$ polymorphism and the risk of hepatocellular carcinoma (HCC) in hepatitis $\mathrm{C}$ viral (HCV) cirrhotic patients as well as its relation to EGF protein expression in HCC tissue. Patients and methods: this casecontrol study was conducted on $75 \mathrm{HCV}$ cirrhotic patients including $50 \mathrm{HCC}$ patients (25 withresectable HCC and 25 with advanced unresectable HCC) and 25 healthy persons were included. EGF genotype was detected by restriction fragment length polymorphism. EGF expression in HCC tissue biopsiesfrom patientswhounderwent surgical resection was done by immunohistochemical examination. Results: The GG genotype was associated with significant increased risk of HCC compared to AA genotypes $(\mathrm{P}=0.031)$ in cirrhotic group. The $\mathrm{G}$ allele had a highly significant risk of $\mathrm{HCC}$ compared to allele Ain recessive model GG vs. $\mathrm{AG}+\mathrm{AA}(\mathrm{P}=0.036)$ rather than in the dominant model $\mathrm{GG}+\mathrm{AG}$ vs. $\mathrm{AA}(\mathrm{P}=0.66)$. There was significant increased expression of $\mathrm{EGF}$ in tumour tissues in patients with GG genotype compared to AG genotype and AA genotype $\mathrm{p}=0.019$. Conclusion: $E G F$ gene polymorphism (GG genotype) had a significant risk of HCC development in cirrhotic patients. This is confirmed by increased $E G F$ expression in liver tumor tissue from HCC patients.
\end{abstract}

Keywords: Epidermal growth factor gene polymorphism- Hepatocellular Carcinoma- Hepatitis C Virus

Asian Pac J Cancer Prev, 21 (7), 2047-2053

\section{Introduction}

Hepatocellular carcinoma (HCC) is the fifth most common cancer and the third leading cause of cancer deaths worldwide (Thrift et al., 2017). Risk factors vary widely in different geographic regions worldwide (Lavanchy and Kane, 2016). In Egypt hepatitis $C$ virus (HCV) infection is a main cause as Egypt has high prevalence of $\mathrm{HCV}$ infection where viremia was reported as 7.3\% (Waked et al., 2014).

Diagnosis of HCC patients occur at the late stage, allowing only minority of the patients to be candidates for possible curative treatments (Li et al., 2010). Pathogenesis of HCC usually correlates with the presence of continuous inflammation and hepatocyte regeneration associated with chronic hepatitis and hepatic cirrhosis(Ringelhan et al., 2018). Genetic factors also have an important role in HCC pathogenesis (Yuan et al., 2013).

Therefore, studying different biomarkers associated with the increased risk of HCC would allow better screening of highrisk populations for HCC and help to improve prevention and treatment (Li et al., 2010).

Epidermal growth factor (EGF) plays a significant role in cell proliferation, differentiation and tumorigenesis of epithelial tissues (Zhong et al., 2012). The EGF 61A>G polymorphism (rs4444903) is a functional SNP in the 5' untranslated region of the $E G F$ gene (Xu et al, 2010, Zhang et al., 2010). It results in higher EGF levels in individuals with EGF genotype $\mathrm{G} / \mathrm{G}$ in comparison to the A/A genotype (Almeida et al., 2010).

Previous studies have shown that EGF rs 4444903 $S N P$ could result in increased risk of tumorigenesis in HCC (Zhong et al., 2012). However, other studies have indicated that thereis no significant association (Qi et al.,

${ }^{1}$ Internal Medicine Department, Faculty of Medicine, Menoufia University, Menoufia, Egypt. ${ }^{2}$ Liver and Hepatobiliary surgery Department, National Liver Institute, Menoufia University, Menoufia, Egypt. ${ }^{3}$ Clinical Pathology Department, National Liver Institute, Menoufia University, Menoufia, Egypt. ${ }^{4}$ Pathology Department, Faculty of Medicine, Menoufia University, Menoufia, Egypt. ${ }^{5}$ Hepatology Department, Mahlla teaching liver hospital, El Mahlla, Gharbeya, Egypt. ${ }^{6}$ Hepatology Gastroenterology Department, National Liver Institute, Menofia University._Egypt.*For Correspondence: ali_nada1981@yahoo.com 
2009).Thus, we aimed to detect the correlation between $E G F$ gene polymorphism and risk of HCC in Egyptian HCVcirrhotic patients. Also validate EGFprotein expression in HCC tissue related to this polymorphism.

\section{Materials and Methods}

\section{Patients and methods}

Study population

This case-control study included 75 patients and 25 healthy individuals matched in age and sex as a control group. Patients were recruited from HCC Clinic, Hepatology Unit,National Liver Institute, Menoufiya University in the duration between February 2017 and February 2018. Study was conducted according to the Declaration of Helsinki. All participants provided written informed consent, and the Ethics Committee of National Liver Institute, Menoufiya University approved the study protocol.

Adult cirrhotic $\mathrm{HCV}$ patients (> 18 years) were eligible to the study. Diagnosis of cirrhosis was done by clinical evaluation, laboratory investigations and abdominal ultrasonography (US). Patients wereclassified according toabdominal US, abdominal tri-phasic computed tomography (CT) and serum alpha fetoprotein (AFP) level into HCC patients and cirrhotic patients with no evidence of HCC.

HCC patients were grouped to patients with surgicalresectable HCC and patients with advanced unresectable HCC (Multicentric hepatic focal lesions with and/ or portal vein thrombosis). Healthy persons, age and sex matched, were enrolledas control group (they were clinicallyfree with normal laboratory investigations, normal abdominal ultrasonography, and no history of liver disease).

Patients withhereditary hepatic diseases,autoimmune liver disorders, other liver cancers, liver disease other than $\mathrm{HCV}$ andhistory of radiological intervention for management of $\mathrm{HCC}$ were excluded.

\section{Laboratory investigations \\ Routine laboratory investigations \\ Liver, renal function testsand random blood sugar were performed on Cobas- 6000 auto analyser (Roche diagnostics- GmbH, D-68305 Mannheim, Germany), prothrombin concentration andinternational normalized ratio (INR) on BFT II Analyzer (Dade Behring Marburg GmbH, D-35041 Marburg, Germany) and seum $\alpha$-fetoprotein level on Cobas e411 immunoassay analyser (Roche diagnostics- GmbH, D-68305 Mannheim, Germany).}

\section{Specific investigations}

I) DNA extraction and EGF genotyping:

Genomic DNA was extracted from venous blood sample using Zymo Quick-gDNA ${ }^{\mathrm{TM}}$ MiniPrep DNA Purification Kit (Zymo Research, CA, USA). The EGF $61 A>G$ Polymorphism ( $r s 4444903$ ) was detected using polymerase chain reaction andrestriction fragment length polymorphism (PCR- RFLP) as previously described (Amend et al., 2004; Suenaga et al., 2013).
PCR amplification of EGF was performed using $1 \mu \mathrm{L}$ of each of the following primers Forward: 5'-TGTCACTAAAGGAAAGGAGGT-3' and reverse 5'-TTCACAGAGTTTAACAGCCC-3'inthe following reaction mixture: $12.5 \mu \mathrm{l}$ of $\mathrm{MyTaq}^{\mathrm{TM}}$ Red Mix master mix (Bioline, MA, USA), $5.5 \mu$ l of nuclease-free Water and $5 \mu \mathrm{l}$ of extracted DNA. Amplification occurred through the following conditions: initial denaturation at $95^{\circ} \mathrm{C}$ for 5 minutes, followed by 35 cycles; $95^{\circ} \mathrm{C}$ for 45 seconds, $51^{\circ} \mathrm{C}$ for 45 seconds, $72^{\circ} \mathrm{C}$ for 45 minute and final extension step of 10 minutes at $72^{\circ} \mathrm{C}$ using Perkin Elmer Gene Amp PCR System 2400 Thermal Cycler.The successful amplification of a $242 \mathrm{bp}$ region of the $E G F$ $61 A>G$ Polymorphism was confirmed using $3 \%$ agarose gel electrophoresis.

Then $10 \mu \mathrm{L}$ DNA amplification product was digested with $1 \mu \mathrm{L}$ Fast Digest AluI restriction enzyme (New England Biolabs) for $5-15 \mathrm{~min}$ at $37^{\circ} \mathrm{C}$. Digestion of the $61{ }^{*} \mathrm{G}$ allele produced 15,34 , and $193 \mathrm{bp}$ fragments, while digestion of the $61 *$ A allele produced 15, 34, 91, and 102 bp fragments.

Detection of EGF in HCC tissue of patients underwent liver resection

Two biopsies were taken from each patient in resectable HCC group, one from neoplasticlivertissue and another one from adjacent non- neoplastic tissue. Both stained with hematoxylin andeosin ( $\mathrm{H}$ and $\mathrm{E}$ ) were examined under the light microscope to confirm the diagnosis of HCC of the neoplastic liver tissue and cirrhosis of the adjacent non-neoplastic tissue.

Then stained immunohistochemically for EGF expression by streptavidin-biotin amplified System.EGF expression was considered positive when $>5 \%$ of the cells showed cytoplasmic brown staining. H score was applied to evaluate the studied cases according to (Bilalovic et al., 2004), where both intensity (scored 1-3 as $1=$ mild, $2=$ moderate and $3=$ strong) and percentage of positive cells were considered.

The intensity score is multiplied by the percentage of cells which stain with each level of intensity, and the sum of these mathematically products is expressed as $\mathrm{H}$ score.

$\mathrm{H}$ score formula $=$ strong intensity (3) $\mathrm{x}$ percentage + moderate intensity (2) x percentage + mild intensity (1) $\mathrm{x}$ percentage.

\section{Statistical analysis}

Results were statistically analyzed by using statistical package of social sciences (SPSS 22.0, IBM/SPSS Inc., Chicago, IL). Categorical data were presented as number and percentage while quantitative data were expressed as mean and standard deviation. Comparison of continuous data between more than two groups was made by using one way ANOVA for parametric data and Kruskal-Wallis test for nonparametric data with post-tests (Turkey and Dunn test, respectively). Chi square test was used for comparison between Categorical data. P-value $<0.05$ was considered significant. 


\section{Results}

Characteristics of the studied subjects

This study included $75 \mathrm{HCV}$ related cirrhotic patients;25 (33.3\%) patients with surgical resectable HCC, $25(33.3 \%)$ patients with advanced unresectable HCC and $25(33.3 \%)$ cirrhotic HCV patients with no evidence of HCC, also 25 subjects were enrolled as control group. $\mathrm{HCC}$, cirrhotic patients and controls had similarage and gender distribution. They were mostly male $(82 \%, 72 \%$
Genetic Polymorphism of Epidermal Growth Factor Gene and $64 \%$ respectively, $p=0.219$ ) (Table 1 ).

We couldn't detect significant difference between HCC group and cirrhotic patients group regarding liver and kidney function tests. However, AFP was significantly higher in HCC group compared to cirrhotic patient group. On the other hand,HCC patients showed significantly elevated ALT, AST, total bilirubin, INR, urea levels and significantly decreased level of albumin compared to control group (Table 2).

Table 1. Statistical Analysis of Demographical Data in HCC, Cirrhosis and Control Groups

\begin{tabular}{|c|c|c|c|c|c|}
\hline Parameters & $\mathrm{HCC}(\mathrm{n}=50)$ & Cirrhosis $(n=25)$ & Control $(n=25)$ & Significance test & $P$-value \\
\hline Age (year) & & & & $F=0.70$ & $0.498^{\mathrm{NS}, \mathrm{a}}$ \\
\hline Mean \pm SD & $57.44 \pm 7.41$ & $58.12 \pm 6.16$ & $55.76 \pm 8.28$ & & \\
\hline Range (min-max) & $43-76$ & $45-71$ & $37-71$ & & \\
\hline Gender $[\mathrm{n}(\%)]$ & & & & $\chi^{2}=3.04$ & $0.219^{\mathrm{NS}, \mathrm{b}}$ \\
\hline Male & $41(82.0)$ & $18(72.0)$ & $16(64.0)$ & & \\
\hline Female & $9(18.0)$ & $7(28.0)$ & $9(36.0)$ & & \\
\hline
\end{tabular}

$\%$, percent within group; ${ }^{a}$, ANOVA test; b, Pearson chi-square test; NS, Non significant at P-value $\geq 0.05$; SD, Standard deviation; $\mathrm{n}$, numberof patients; HCC, Hepatocellular carcinoma; GI, group1; Min, Minimum,; Max, Maximum

Table 2. Statistical Analysis Ofbiochemical Lab Parameters in HCC, Cirrhosis and Control Groups

\begin{tabular}{|c|c|c|c|c|c|}
\hline Biochemical parameters & $\begin{array}{c}\text { HCC } \\
(n=50)\end{array}$ & $\begin{array}{l}\text { Cirrhosis } \\
(\mathrm{n}=25)\end{array}$ & $\begin{array}{l}\text { Control } \\
(\mathrm{n}=25)\end{array}$ & Significance test & Pairwise comparisons* \\
\hline ALT (U/L) & & & & $\chi^{2}=41.37$ & $P_{I}=1.000^{\mathrm{NS}}$ \\
\hline Median (IQR) & $63.50(44.75)$ & $56.00(23.50)$ & $26.00(11.00)$ & $P$-value & $P_{2}<0.001^{\mathrm{HS}}$ \\
\hline Range (min-max) & $11.00-404.00$ & $31.00-98.00$ & $11.00-51.00$ & $<0.001^{\mathrm{HS}, \mathrm{a}}$ & $P_{3}<0.001^{\mathrm{HS}}$ \\
\hline AST (U/L) & & & & $\chi^{2}=42.17$ & $P_{l}=1.000^{\mathrm{NS}}$ \\
\hline Median (IQR) & $67.00(68.25)$ & $65.00(37.50)$ & $24.00(12.50)$ & $P$-value & $P_{2}<0.001^{\mathrm{HS}}$ \\
\hline Range (min-max) & $12.00-534.00$ & $23.00-243.00$ & $12.00-49.00$ & $<0.001^{\mathrm{HS}, \mathrm{a}}$ & $P_{3}<0.001^{\mathrm{HS}}$ \\
\hline Total bilirubin (mg/dL) & & & & $\chi^{2}=34.79$ & $P_{I}=0.213^{\mathrm{NS}}$ \\
\hline Median (IQR) & $1.65(2.90)$ & $2.10(1.45)$ & $0.80(0.20)$ & $P$-value & $P_{2}<0.001^{\mathrm{HS}}$ \\
\hline Range (min-max) & $0.30-10.00$ & $1.30-5.20$ & $0.50-1.30$ & $<0.001^{\mathrm{HS}, \mathrm{a}}$ & $P_{3}<0.001^{\mathrm{HS}}$ \\
\hline Albumin $(\mathrm{g} / \mathrm{dL})$ & & & & $\chi^{2}=56.69$ & $P_{I}=0.001^{\mathrm{HS}}$ \\
\hline Median (IQR) & $3.30(1.20)$ & $2.60(0.84)$ & $4.30(0.60)$ & $P$-value & $P_{2}<0.001^{\mathrm{HS}}$ \\
\hline Range (min-max) & $1.90-4.60$ & $1.70-3.30$ & $3.70-5.00$ & $<0.001^{\mathrm{HS}, \mathrm{a}}$ & $P_{3}<0.001^{\mathrm{HS}}$ \\
\hline INR value & & & & $\chi^{2}=28.67$ & $P_{1}=0.153^{\mathrm{NS}}$ \\
\hline Median (IQR) & $1.40(0.60)$ & $1.90(0.70)$ & $1.00(0.20)$ & $P$-value & $P_{2}<0.001^{\mathrm{HS}}$ \\
\hline Range (min-max) & $0.90-3.10$ & $1.00-3.10$ & $0.90-1.30$ & $<0.001^{\mathrm{HS}, \mathrm{a}}$ & $P_{3}<0.001^{\mathrm{HS}}$ \\
\hline Urea (mg/dL) & & & & $\chi^{2}=22.98$ & $P_{l}=1.000^{\mathrm{NS}}$ \\
\hline Median (IQR) & $54.00(22.00)$ & $54.00(44.50)$ & $33.00(12.50)$ & $P$-value & $P_{2}<0.001^{\mathrm{HS}}$ \\
\hline Range (min-max) & $21.00-190.00$ & $12.00-98.00$ & $17.00-53.00$ & $<0.001^{\mathrm{HS}, \mathrm{a}}$ & $P_{3}=0.001^{\mathrm{HS}}$ \\
\hline Creatinine $(\mathrm{mg} / \mathrm{dL})$ & & & & $\chi^{2}=2.25$ & - \\
\hline Median (IQR) & $1.00(0.53)$ & $1.10(0.70)$ & $1.00(0.20)$ & $P$-value & \\
\hline Range (min-max) & $0.40-2.30$ & $0.40-2.40$ & $0.70-1.30$ & $=0.325^{\mathrm{NS}, \mathrm{a}}$ & \\
\hline $\mathrm{RBS}(\mathrm{mg} / \mathrm{dL})$ & & & & $\chi^{2}=5.40$ & - \\
\hline Median (IQR) & $110.00(47.25)$ & $98.00(44.00)$ & $105.00(27.00)$ & $P$-value & \\
\hline Range (min-max) & $65.00-364.00$ & $68.00-243.00$ & $62.00-145.00$ & $=0.067^{\mathrm{NS}, \mathrm{a}}$ & \\
\hline $\operatorname{AFP}(\mathrm{ng} / \mathrm{mL})$ & & & & $z=4.58$ & - \\
\hline Median (IQR) & $62.50(226.25)$ & $17.00(16.50)$ & - & $P$-value & \\
\hline Range (min-max) & $5.40-151000.00$ & $3.10-68.00$ & - & $<0.001^{\mathrm{HS}, \mathrm{b}}$ & \\
\hline
\end{tabular}

IQR, Interquartile range; NS, Non significant at P-value $\geq 0.05$; HS, Highly significant at P-value $<0.01 ;{ }^{a}$, Kruskal-Wallis test; ${ }^{\mathrm{b}}$, Mann-Whitney U test ; *, Multiple pairwise comparisons adjusted by Bonferronipost hoc test; $P, \mathrm{P}$-value for the difference between HCC and cirrhosis groups; $P_{2}, \mathrm{P}$-value for the difference between HCC and control groups; $P_{3}, \mathrm{P}$-value for the difference between cirrhosis and control groups. 
Table 3. Comparison of Genotypes Distribution and Allele Frequencies of EGF Polymorphism (61 A/G) in HCC versus Cirrhoticpatients

\begin{tabular}{|c|c|c|c|c|}
\hline EGF Polymorphism $61 \mathrm{~A} / \mathrm{G}$ & $\mathrm{HCC}(\mathrm{n}=50)$ & Cirrhosis $(n=25)$ & OR $(95 \% \mathrm{CI})$ & $P$-value \\
\hline \multicolumn{5}{|l|}{ Genotypes [n (\%)] } \\
\hline GG & $20(40.0)$ & $4(16.0)$ & $5.71(1.30-25.03)$ & $0.031^{\mathrm{S}, \mathrm{a}}$ \\
\hline $\mathrm{AG}$ & $23(46.0)$ & $13(52.0)$ & $2.02(0.60-6.86)$ & $0.255 \mathrm{~N}^{\mathrm{S}, \mathrm{b}}$ \\
\hline AA & $7(14.0)$ & $8(32.0)$ & Ref. & - \\
\hline \multicolumn{5}{|l|}{ Dominant model ${ }^{1}$} \\
\hline $\mathrm{GG}+\mathrm{AG}$ & $43(86.0)$ & $17(68.0)$ & $2.89(0.91-9.22)$ & $0.066^{\mathrm{NS}, \mathrm{a}}$ \\
\hline AA & $7(14.0)$ & $8(32.0)$ & Ref. & - \\
\hline \multicolumn{5}{|l|}{ Recessive model $^{2}$} \\
\hline GG & $20(40.0)$ & $4(16.0)$ & $3.50(1.04-11.73)$ & $0.036^{\mathrm{S}, \mathrm{b}}$ \\
\hline $\mathrm{AG}+\mathrm{AA}$ & $30(60.0)$ & $21(84.0)$ & Ref. & - \\
\hline \multicolumn{5}{|l|}{ Alleles [n (\%)] } \\
\hline G & $63(63.0)$ & $21(42.0)$ & $2.35(1.18-4.70)$ & $0.015^{\mathrm{S}, \mathrm{b}}$ \\
\hline A & $37(37.0)$ & $29(58.0)$ & Ref. & - \\
\hline
\end{tabular}

a, Fisher's Exact test; ${ }^{\text {b }}$, Pearson Chi-Square test; \%, percent of genotype or allele within group-NS : Non significant at P-value $\geq 0.05 ;{ }^{1}$, Dominant model, (homozygous type + hybrid type)vs. wild type; ${ }^{2}$, Recessive model,homozygous vs. (hybrid type+ wild type)

Frequency of EGF 61A>G SNP among studied groups and its risk effect

$\mathrm{G}$ allele showed statistical higher frequency in $\mathrm{HCC}$ group $(63 \%)$ compared to cirrhotic patients $(42 \%)$ and control group $(38 \%)(p=0.005)$, with increased GG genotype in HCC group (40\%) compared to cirrhotic patient group (16\%) and control group $(12 \%)(p=0.029)$.

Compared to cirrhotic patients, GG genotype was associated with significant increased risk of HCC compared to AA genotype with OR (95\% CI) 5.71, $(\mathrm{P}=0.031)$. The $\mathrm{G}$ allele carried a highly significant risk of HCC compared with allele A OR (95\% CI) 2.35, ( $P$ value $=0.015)$. The variant $\mathrm{G}$ allele showed a significant association with HCC risk in the recessive model GG vs. $\mathrm{AG}+\mathrm{AA}(\mathrm{P}=0.036)$ rather than the dominant model $\mathrm{GG}+\mathrm{AG}$ vs. AA $(\mathrm{P}=0.066)($ Table 3$)$. We couldn'tdetect significant difference in genotype distribution and allele frequencies of EGF polymorphism between resectable and unresectable HCC patients (Table 4)

\section{Studying effect of genotype distribution on resectable HCC group}

There was similarity in age and gender distribution regarding different genotypes in resectable HCC group. We couldn't detect significant difference infoci size or AFP levels. However, there was significant increased expression of EGF in tumour tissues $(200.00 \pm 28.78)$ in patients with GG genotype compared to AG genotype (162.31 \pm 30.86$)$ and AA genotype (152.50 \pm 35.00$)$, $\mathrm{p}=0.019$. Also, expression of EGF in surrounding cirrhotic tissue was elevated in GG genotype (162.50 \pm 53.12) compared to AG genotype (138.46 \pm 53.52$)$ and AA genotype (140.00 \pm 73.48$)$, however we couldn't find significant difference, $\mathrm{p}=0.626$ (Table 5).

Table 4. Comparison of Genotype Distribution and Allele Frequencies of EGF Polymorphism (61 A/G) Inresectable versus Unresectable HCC Patients

\begin{tabular}{|c|c|c|c|c|}
\hline EGF Polymorphism $61 \mathrm{~A} / \mathrm{G}$ & Resectable HCC $(\mathrm{n}=25)$ & Unresectable $(\mathrm{n}=25)$ & OR $(95 \% \mathrm{CI})$ & $P$-value \\
\hline \multicolumn{5}{|l|}{ Genotypes [n (\%)] } \\
\hline GG & $8(32.0)$ & $12(48.0)$ & $2.00(0.35-11.44)$ & $0.662^{\mathrm{NS}, \mathrm{a}}$ \\
\hline AG & $13(52.0)$ & $10(40.0)$ & $1.03(0.19-5.66)$ & $1.000^{\mathrm{NS}, \mathrm{a}}$ \\
\hline AA & $4(16.0)$ & $3(12.0)$ & Ref. & - \\
\hline \multicolumn{5}{|l|}{ Dominant model ${ }^{1}$} \\
\hline $\mathrm{GG}+\mathrm{AG}$ & $21(84.0)$ & $22(88.0)$ & $1.40(0.28-7.00)$ & $1.000^{\mathrm{NS}, \mathrm{a}}$ \\
\hline $\mathrm{AA}$ & $4(16.0)$ & $3(12.0)$ & Ref. & - \\
\hline \multicolumn{5}{|l|}{ Recessive model $^{2}$} \\
\hline GG & $8(32.0)$ & $12(48.0)$ & $1.96(0.62-6.19)$ & $0.248^{\mathrm{NS}, \mathrm{b}}$ \\
\hline $\mathrm{AG}+\mathrm{AA}$ & $17(68.0)$ & $13(52.0)$ & Ref. & - \\
\hline \multicolumn{5}{|l|}{ Alleles [n (\%)] } \\
\hline G & $29(58.0)$ & $34(68.0)$ & $1.54(0.68-3.49)$ & $0.300^{\mathrm{NS}, \mathrm{b}}$ \\
\hline A & $21(42.0)$ & $16(32.0)$ & Ref. & - \\
\hline
\end{tabular}

a, Fisher's Exact test; ${ }^{\text {b }}$ Pearson Chi-Square test; \%, percent of genotype or allele within group; NS, Non significant at P-value $\geq 0.05 ;{ }^{1}$, Dominant model, (homozygous type + hybrid type)vs. wild type; ${ }^{2}$, Recessive model,homozygous vs. (hybrid type+ wild type) 


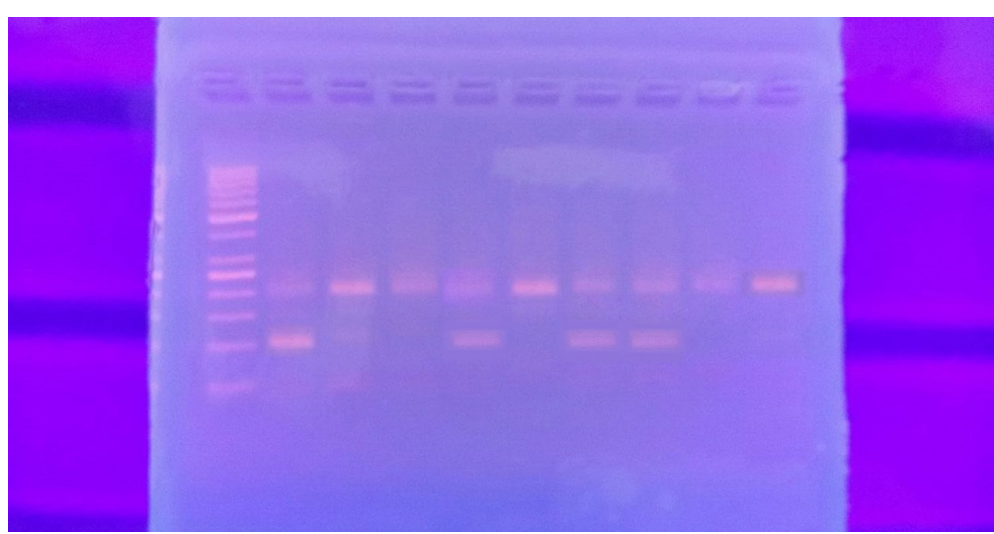

Figure 1. Showing Agarose Gel Electrophoresis after Digestion UsingAlu I Restriction Enzyme for Detection ofEGF 61A > G Polymorphism(rs4444903). Lane 1 50-bp DNA ladder, lane 2, 5, 7 \& 8A/G heterozygous (91, 102 and 193 bp bands), lane 3, 4, 6, 9 \& 10G/G homozygous (193 bp bands). N.B. 15, 34 bp bands were short and not detected

\section{Discussion}

Liver carcinogenesis is a complex and multi-factorial process, in which many signaling pathways could contribute to malignant transformation. EGF, through epidermal growth factor receptor (EGFR) acts as mitogen stimulating cellular proliferation and differentiation (Modica et al., 2019). Besides, EGF was suggested to contribute to the occurrence of inflammation and HCC (Berasain et al, 2009 andHuang et al, 2014).

$E G F$ gene is $110 \mathrm{~kb}$ in length. It contains 24 exons, and is located on human chromosome $4 \mathrm{q} 25$. A single nucleotide polymorphism $(S N P) 61 A>G$ located in the $5^{\prime}$ untranslated region influences the expression levels of EGF, where G/G genotype is associated with elevated EGF expression(Wu et al., 2013).

Our present study showed thatA allele was more prevalent in the control group (62\%). While, G allele was significantly dominant in HCC patients $63 \%$ in HCC patients compared to $42 \%$ in cirrhoticpatients. $\mathrm{G}$ allele showed significantly high risk for HCC compared to cirrhosis $(95 \% \mathrm{CI}) 2.35(\mathrm{P}=0.015)$.

These results proved that the $\mathrm{G}$ allele may have the risk of hepatocarcinogenesis, while A may be theprotective allele. These results were similar to previous reports (Abu Dayyehet al., 2011- Sun et al., 2015).

Table 5. Statistical Analysis of Biochemical and Clinical Parametersregarding Genotypes Ofegf Polymorphism (61 $\mathrm{A} / \mathrm{G}$ ) in Resectable HCC Patients

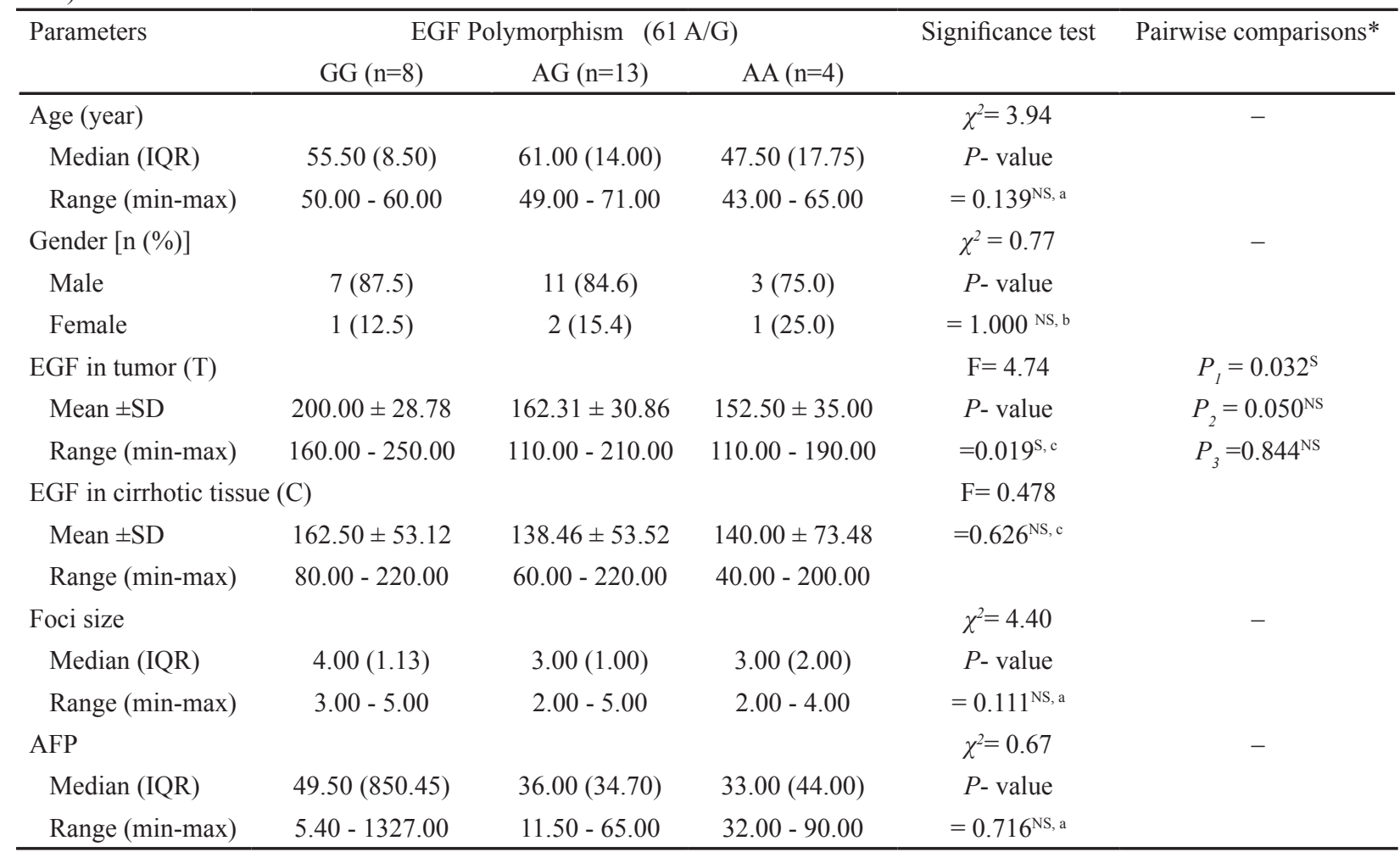

$\%$, percent within group; IQR, Interquartile range; ${ }^{\text {, }}$ Kruskal-Wallis test; ${ }^{\text {, }}$, Fisher's exact test; ${ }^{\mathrm{c}}$, ANOVA test; NS, Non significant at P-value $\geq 0.05$; S, Significant at P-value $<0.05$; *, Multiple pairwise comparisons adjusted by Tukey HSDpost hoc test; $P_{l}$, P-value for the difference between genotypes GG vs. AG; $P_{2}$, P-value for the difference between genotypes GG vs. AA; $P_{3}$, P-value for the difference between genotypes AG vs. AA. 
Tanabe et al., (2008) demonstrated that the half- life of mRNA transcripts from the $\mathrm{G}$ allele was significantly longer than that from A allele. They concluded that the increased stability of transcribed mRNA could explain theincreased risk with $G$ allele. Similar results were reported by Suenaga et al, 2013.

However, a studyconducted by Qi et al, 2009conflicted our results. Theyfailed to find a significant association between EGF61A/G SNP and risk of HCC(Qi et al, 2009). In addition, a study directed by Gholizadehet al, 2017 on chronic HCV infected Iranian patientsshowed that frequency of the EGF 61A allele in HCC patients was significantly higher than the healthy controls $(\mathrm{P}$ value $=$ 0.04). They proposed that the increased risk of HCC with different genotypes might be dependent on the population.

Regarding EGF protein expression in HCC tissue, our present study showed that there was higher concentration of EGF in the tumor tissue $(\mathrm{T})(200.00 \pm 28.78)$ in patients with GG genotype compared to AG genotype (162.31 \pm $30.86)$ and AA genotype $(152.50 \pm 35.00), p=0.019$. This means that functional polymorphism in the $E G F$ gene can modifyits protein production.

These results matched withLi et al., (2010) immunohistochemical results of HCC liver tissue. They showed that samples with the GG genotype expressed EGF protein more than those with the AG genotype. In addition, a study conducted by Liu et al., (2018) demonstrated that the expression of EGF in HCCs was significantly higher compared with that in normal tissues, which indicates that EGF is highly expressed in HCC microenvironment. Furthermore, higher level of EGF was significantly associated with higher grade, which suggest that EGF may stimulate progression of HCCs.

To conclude, in the present study, EGF gene polymorphism $61^{*} \mathrm{G}$ was associated with increased $\mathrm{HCC}$ risk(patients with $\mathrm{G} / \mathrm{G}$ genotype having more risk than $\mathrm{A} / \mathrm{G}$ and $\mathrm{AA}$ ). This is confirmed byincreased EGF expression in tumor tissue of $\mathrm{G} / \mathrm{G}$ genotype. This could increase the risk of HCC in cirrhotic HCV Egyptian patients. Thus, patients carrying the risk alleles should be closely followed up for early diagnosis and better outcome of treatment.

\section{Acknowledgments}

All authors contributed equally. There were no competing interests.

\section{Authors contribution to work}

Conception of the study, Ibrahim Baghdadi; design of the study, Khaled Abu Ella; Investigation, Ahmed Elshaarawy and Mary Naguib; Methodology, Ahmed Elshaarawy, Hala S. El-Rebey and Mary Naguib; Formal analysis, ElsayedElshayb; writing original draft, Mohamed M. Elhoseeny, Mary Naguib and Ali Nada; Writing- review and editing, Ibrahim Baghdadi, Khaled Abu Ella, Ahmed Elshaarawy, ElsayedElshayb, Hala S. El-Rebey, Mohamed M. Elhoseeny, Mary Naguib and Ali Nada

\section{Ethical approval and informed consent}

Study was conducted according to the Declaration of Helsinki. Protocol of the study was approved by Institution Review Board of National Liver Institute Menoufiya University. All participants provided written informed consent.

\section{References}

Abbas E, Shaker O, Abd El Aziz G, et al (2012). Epidermal growth factor gene polymorphism $61 \mathrm{~A} / \mathrm{G}$ in patients with chronic liver disease for early detection of hepatocellular carcinoma: a pilot study. Eur J Gastroenterol Hepatol, 24, 458-63.

Abu Dayyeh BK, Yang M, Fuchs BC, et al (2011). A functional polymorphism in the epidermal growth factor gene is associated with risk for hepatocellular carcinoma. Gastroenterology, 141, 141-9.

Almeida LO, Custódio AC, Santos MJ, et al (2010). The A61G EGF polymorphism is associated with development of extraaxial nervous system tumors but not with overall survival. Cancer Genet Cytogenet, 198, 15-21.

Amend KL, Elder JT, Tomsho LP, et al (2004). EGF gene polymorphism and the risk of incident primary melanoma. Cancer Res, 64, 2668-72.

BerasainC, Perugorria MJ, Latasa MU, et al (2009). The epidermal growth factor receptor: a link between inflammation and liver cancer. Exp Biol Med (Maywood), 7, 713-25

GholizadehM, Khosravi A, Torabian P, et al (2017). Association of the epidermal growth factor gene $+61 \mathrm{~A}>\mathrm{G}$ polymorphism with hepatocellular carcinoma in an Iranian population. Gastroenterol Hepatol Bed Bench, 10, 284-8.

Huang P, Xu X, Wang L, et al (2014). The role of EGF-EGFR signalling pathway in hepatocellular carcinoma inflammatory microenvironment. J Cell Mol Med, 18, 218-30.

Jiang G, Yu K, Shao L, et al (2015). Association between epidermal growth factor gene $+61 \mathrm{~A} / \mathrm{G}$ polymorphism and the risk of hepatocellular carcinoma: a meta-analysis based on 16 studies. BMC Cancer, 15, 314.

Lavanchy D, Kane M (2016). Global Epidemiology of Hepatitis B Virus Infection. Molecular and Translational Medicine. Springer International Publishing, pp 187-203.

Li Y, Xie Q, Lu F, et al (2010). Association between epidermal growth factor $61 \mathrm{~A} / \mathrm{G}$ polymorphism and hepatocellular carcinoma susceptibility in Chinese patients. Liver Int, 30, 112-8.

Liu Z, Chen D, Ning F, et al (2018). EGF is highly expressed in hepatocellular carcinoma (HCC) and promotes motility of HCC cells via fibronectin. J Cell Biochem, 119, 4170-83.

ModicaTME, Dituri F, Mancarella S, et al (2019).Calcium regulates HCC proliferation as well as EGFR recycling/ degradation and could be a new therapeutic target in HCC. Cancers (Basel), 18, 11, pii: E1588.

Qi P, Wang H, Chen YM, et al (2009). No association of EGF 5'UTR variant A61G and hepatocellular carcinoma in Chinese patients with chronic hepatitis B virus infection. Pathology, 41, 555-60.

RingelhanM, McKeating JA, Protzer U (2017). Viral hepatitis and liver cancer [published correction appears in Philos Trans R Soc Lond B Biol Sci. 2018 Jan 5;373(1737):]. Philos Trans R Soc Lond B Biol Sci., 372, 20160274. doi:10.1098/ rstb.2016.0274

SuenagaM, Yamada S, Fujii T, et al (2013). A functional polymorphism in the epidermal growth factor gene predicts hepatocellular carcinoma risk in Japanese hepatitis C patients. Onco Targets Ther, 13, 1805-12. 
Sun S, Jin GJ, Zhao Y, et al (2015). Association between the epidermal growth factor $61 * \mathrm{~A} / \mathrm{G}$ polymorphism and hepatocellular carcinoma risk: a meta-analysis. Asian Pac J Cancer Prev, 16, 3009-14.

Tanabe KK, Lemoine A, Finkelstein DM, et al (2008). Epidermal growth factor gene functional polymorphism and the risk of hepatocellular carcinoma in patients with cirrhosis. JAMA, 299, 53-60.

Thrift AP, El-Serag HB andKanwal F (2017). Global epidemiology and burden of HCV infection and HCV-related disease. Nat Rev Gastroenterol Hepatol, 14, 122-32.

Waked I, Doss W, El-Sayed M, et al (2014). The current and future disease burden of chronic hepatitis $\mathrm{C}$ virus infection in Egypt. Arab J Gastroenterol, 15, 45-52.

Wu D, Wu Y, Zhang X, et al (2013).Lack of association between $\mathrm{EGF}+61 \mathrm{~A}>\mathrm{G}$ polymorphism and melanoma susceptibility in Caucasians: a HuGE review and meta-analysis. Gene, 25, 359-66.

Xu W, Li Y, Wang X, et al (2010). Association between EGF promoter polymorphisms and cancer risk: a meta-analysis. Med Oncol, 27, 1389-97.

Yuan JM, Fan Y, Ognjanovic S, et al (2013). Genetic polymorphisms of epidermal growth factor in relation to risk of hepatocellular carcinoma: two case-control studies. BMC Gastroenterol, 13, 32.

Zhang YM, Cao C, Liang K (2010) Genetic polymorphism of epidermal growth factor 61Aandgt; $\mathrm{G}$ and cancer risk: a meta-analysis. Cancer Epidemiol, 34, 150-6.

Zhong JH, You XM, Gong WF, et al (2012). Epidermal growth factor gene polymorphism and risk of hepatocellular carcinoma: a meta-analysis. PLoS One, 7, e32159.

ZhongJH, You XM, Gong WF, et al (2012). Epidermal growth factor gene polymorphism and risk of hepatocellular carcinoma: A Meta-Analysis. PLoS One, 7, e32159.

\section{c) (1) 8)}

This work is licensed under a Creative Commons AttributionNon Commercial 4.0 International License. 